\title{
The Level of Competency Knowledge in Safety Training among Construction Personnel
}

\author{
"Erita Mazwin Mazlan', Mohd Hanim Osman² and \\ Muhammad Sukri Saud ${ }^{3}$
}

Published online: 31 December 2019

To cite this article: Erita Mazwin Mazlan, Mohd Hanim Osman and Muhammad Sukri Saud (2019). The level of competency knowledge in safety training among construction personnel. Journal of Construction in Developing Countries, 24(2): $157-172$. https://doi.org/10.21315/jcdc2019.24.2.7.

To link to this article: https://doi.org/10.21315/jcdc2019.24.2.7

\begin{abstract}
Competency in safety is important for construction personnel and it is compulsory for all construction personnel in Malaysia to attend safety training. A literature review of the recommended training module revealed gaps in evaluating the effectiveness of competency knowledge among 200 construction personnel. Therefore, this article investigates the level of competency knowledge among construction personnel towards construction accidents based on safety training in Malaysia's construction industry. A structured, self-administered questionnaire was designed and used to assess the level of competency knowledge in safety training. For each participant, the knowledge score was calculated by dividing the sum of correct answers by the total number of correct responses. The average knowledge score for all participants was $92 \%$, whereas designers and site supervisors obtained better scores $194 \%$ and $91 \%$, respectively) than contractors (90\%). The knowledge scores among all construction personnel are not significantly associated with age and experience. Results indicated that there were nine topics with a significant difference in competency knowledge $(p<0.005)$ which were transportation and mobile plant, installation of steel frame, roof work, personal protective equipment (PPE), working in the water area, welding and cutting, manual work, noise and vibration and accident prevention.
\end{abstract}

Keywords: Safety training, Competency knowledge, Site supervisors, Designers, Contractors

\section{INTRODUCTION}

Safety in construction sites is of utmost importance which makes it fundamental to distinguish the competency level, training and knowledge, along with management and supervisory skills in safety among construction personnel. This is necessary because incompetency and inadequacy in these areas among construction personnel may increase the risk factors in the occurrences of accidents, incidents, injuries, fatalities and loss of property on construction sites (Argote, 1999; Langford, Rowlinson and Sawacha, 2000; Goh, 2002; Schindler and Eppler, 2003). Interestingly, the occurrences of such event are also identified as major factors used to measure up safety and health performances between developed and developing nations (Chiocha, Smallwood and Emuze, 2011). Therefore, it is worthy to mention that there are a total of 763 cases of construction accidents filed in Malaysia between 2007

\footnotetext{
'Centre for Engineering Education, Universiti Teknologi Malaysia (UTM), 81300 Skudai, Johor Bahru, Johor, MALAYSIA

${ }^{2}$ Forensic Engineering Centre, Institute of Smart Infrastructures and Innovative Construction, Universiti Teknologi Malaysia (UTM), 81300 Skudai, Johor Bahru, Johor, MALAYSIA

${ }^{3}$ Faculty of Education, Universiti Teknologi Malaysia (UTM), 81300 Skudai, Johor Bahru, Johor, MALAYSIA

*Corresponding author: eritamazlan@gmail.com
} 
to 2012 and 422 or a concerning $55 \%$ of the number involved fatality accidents as recorded by the Department of Occupational Safety and Health (DOSH), Ministry of Human Resources (DOSH, 2012). Therefore, this whopping figure further fortifies the requirement for construction personnel to have adequate competency in construction safety. Not only that, there is approximately 60,000 incidences recorded globally which caused fatality and grievous injuries attributable to the lack of competency skills and knowledge in construction safety among construction personnel (International Labour Organization, 2003). Such alarming figure calls for the need to create a safe working environment through emphasising to the employees on the importance of following the standard safety precautions and knowing the potential hazards so that appropriate safety measures could be executed (Salleh et al., 2011).

Despite knowing the importance of training and knowledge for construction safety and conforming to regulations, many still do not take these as inherent factors for healthy work environment. It has also been brought to light that many construction personnel repeated similar mistakes at the expense of others' safety due to insufficient emphasis on learning and practising practical knowledge, while yielding to safety regulations (Mohamed et al., 2007; Tam et al., 2003). Such an offhand manner leads to the practice of inappropriate techniques in managing and disseminating knowledge to other colleagues (Jones and Saad, 2003). This situation was brought to attention in Hong Kong where knowledge or experience gained by the construction personnel was poorly delivered causing undue grievances for some of the identified projects (Gue and Tan, 2004). Adding to the shocking finding in Hong Kong, deficiency of knowledge and reluctance to contribute input source to safety were also identified to be among the much unwarranted causes of accidents in China (Tam, Zeng and Deng, 2004) and Taiwan (Chen et al., 2013). Failure to follow safety compliance in other matters such as using materials which are noncompliant to standards or specifications, insufficient soil investigations, weak foundations and poor site layout lead to many construction accidents (Alnunu and Maliha, 2015; Lubega, Kiggundu and Tindiwensi, 2000). Therefore, factors which may contribute to construction hazards need to be thoroughly looked into to avoid unnecessary mishaps and losses.

It is without doubt that construction personnel need to have all the necessary knowledge for effective safety practices while getting the required and continuous training. This has been clearly suggested in various studies including that in the "Model of Effective Job Performance" which demonstrated that ineffective behaviour or inaction are likely to occur when competency knowledge does not correspond with job performance (Boyatzis, 1982; Demirkesen and Arditi, 2015). Safety knowledge and the awareness level of construction personnel are interrelated behavioural displays which affect any form of incidents in construction. Realising the importance of safety in the construction industry, the Construction Industry Development Board (CIDB) conducts safety training to deliver necessary knowledge for construction personnel. Upon getting the necessary training, construction personnel are expected to have more in-depth knowledge on safety which should be demonstrated in their daily practices at work. This in turn should improve their abilities to identify any possible risks and hazards connected to the workplace. Therefore, this study aims to investigate the level of competency knowledge in safety training among construction personnel at various positions such as the site supervisors, designers which include the architects, project managers, quantity surveyors and consultant engineers, and contractors. 


\section{MATERIALS AND METHODS}

\section{Selection of Construction Personnel}

The study uses convenient sampling to obtain representative samples at several courses attended as organised by CIDB which involved 200 construction personnel. The participants are construction personnel who are of technical background with extensive working experience in construction and are equipped with safety knowledge. The participants were provided with all the necessary information of the research with clear instructions on how to complete the questionnaire distributed to them while the researchers had personally administered and collected the questionnaires at the end of the course.

\section{Questionnaire}

A questionnaire-based survey was carried out in this study comprising of three major parts. These parts include the following: Part 1 requires the participants to provide their demographic information, Part 2 seeks the participants' knowledge on construction accidents and Part 3 attempts to collect information on the participants' knowledge in minimising construction accidents.

The questions for Part 2 and Part 3 were developed based on a multiple questions because it is the most common and widely used assessment tool for the measurement of knowledge, ability and complex learning outcomes (Gronlund, 1993; Ben-Simon, Budescu and Nevo, 1997) and extensively used (Merwe, 2015). Induction training modules provided by CIDB were used as a reference to develop the multiple choice questions. The questionnaire contained 50 questions grouped into 25 main topics. The descriptions of these 25 main topics are as follow: Topic 1: Laws and regulations, Topic 2: Housekeeping and cleanliness, Topic 3: Fire prevention, Topic 4: Welfare facilities, Topic 5: Hazards from electric, Topic 6: Portable power tools, Topic 7: Transportation and mobile plant, Topic 8: Crane, Topic 9: Hoist, Topic 10: Excavation, Topic 11: Demolition, Topic 12: Installation of steel frame, Topic 13: Roof work, Topic 14: Ladder usage, Topic 15: Personal protective equipment (PPE), Topic 16: Scaffolding, Topic 17: Working on live roads, Topic 18: Working in water area, Topic 19: Confined space, Topic 20: Welding and cutting, Topic 21: Manual work, Topic 22: Chemical dust and fumes and heat, Topic 23: Noise and vibration, Topic 24: Heat, Topic 25: Accident prevention (Teck et al., 2015).

Part 2 involves some theory questions to seek the construction personnel's knowledge of construction accidents through 14 close-ended questions with two possible answers "True" and "False". These theory questions focused on issues regarding responsibility of both employer and employee under laws and regulations, personnel protective equipment, housekeeping and cleanliness, chemical hazards and roof work. For each right answer, one point was awarded.

Part 3 attempts to assess the level of knowledge of the construction personnel through 36 close-ended questions regarding practical work in construction such as housekeeping and cleanliness, fire prevention, electric hazards, transportation and mobile plant, excavation, roof work, working on live roads, chemical hazards, working at height and personnel protective equipment. The construction personnel will also be required to organise their answers in the order of their preferences and 
their scores will be dictated by the preference that they have assigned in their answers. The setting of the individual's acceptance level is referred to response criterion. The correct acceptance is referred to as a hit and will be analysed.

\section{DATA ANALYSIS}

The knowledge score for each participant in Part 2 and Part 3 were calculated by dividing the sum of correct answers by the total number of correct responses. Independent sample t-test (for two groups, such as gender) was used to analyse knowledge scores. The score level was based on the level of success and the range of marks (as shown in Table 1). Analysis of Variance (ANOVA) with the Scheffe test was used for more than two groups such as age and experience in construction. To identify knowledge gaps, the Chi-square test was used to compare the percentage of correct replies to each question across the three types of construction personnel namely, site supervisors, designers which include the architects, project managers, quantity surveyors and consultant engineers, and contractors. Values with $p<0.05$ were considered statistically significant.

Table 1. Level of Success with the Range of Marks

\begin{tabular}{lcc}
\hline Level of Success & Range of Marks & Score \\
\hline Excellent & $76-100$ & 4 \\
Good & $51-75$ & 3 \\
Fair & $26-50$ & 2 \\
Weak & $0-25$ & 1 \\
\hline
\end{tabular}

Source: Ministry of Education Malaysia (2016)

\section{RESULTS}

\section{Sample Characteristics}

Of the 200 construction personnel who participated in this study, 53\% of the construction personnel were contractors, $35.5 \%$ were designers and $12 \%$ were site supervisors. This figure is made up of $66 \%$ male and $34 \%$ female participants respectively (as shown in Table 2). A majority of $36 \%$ participants were 45 years old while those between the ages of 26 to 35 and 36 to 45 were made of $25 \%$ each from the total number of participants and $14 \%$ of the participants were below 25 years old. It is worthy to note that $40 \%$ of the participants had less than five years of work experience, with $38 \%$ of them had between six to 15 years of work experience and $13 \%$ had between 16 to 25 years of work experience and an interesting figure of $19 \%$ had more than 25 years of work experience. It is also worthy to note that all of the participants had participated in mandatory safety training as legislated since 1997. 


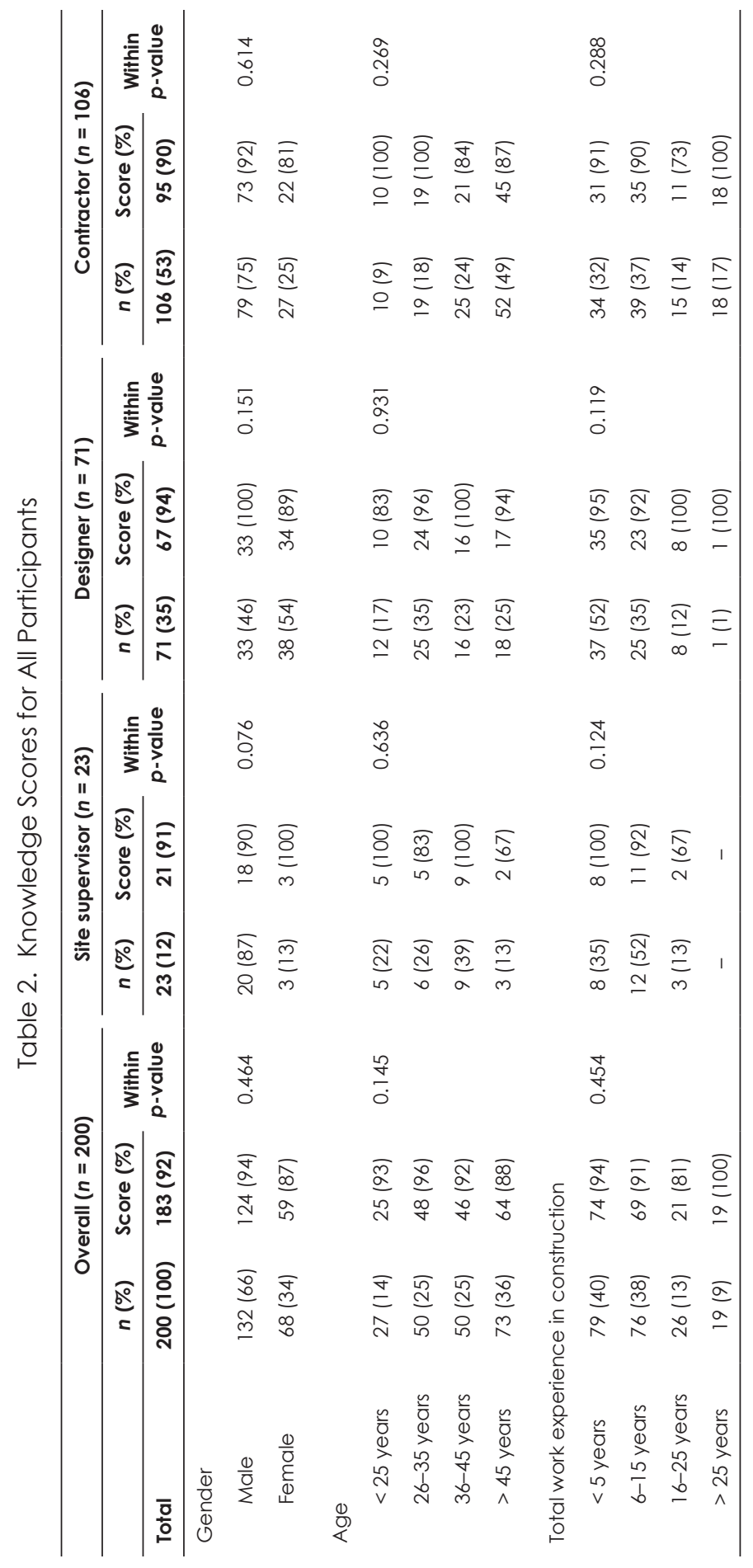




\section{Knowledge Scores within Different Construction Personnel}

A significant value of $92 \%$ of the participants scored in excellence for overall knowledge on safety. Most interestingly enough, designers had the highest percentage of knowledge in safety marking a whopping $94 \%$ followed closely with $91 \%$ by site supervisors and a marginal value of $90 \%$ by contractors (Table 2). In contrast, an earlier report by Chen, Lu and Huang (2011) demonstrated that the mean cognition score for both technical and contractor personnel are much higher in safety cognition levels with the contractors having a score of $\geqq 80 \%$ while the designers were equipped with low safety cognition levels $<75 \%$.

\section{Knowledge and Awareness Scores for Construction Personnel}

The knowledge score among construction personnel was significantly associated with age $(p<0.145)$ and experience $(p<0.454)$ (as shown in Table 2$)$. The participants in the age group of 26 to 35 years old obtained excellently at $90 \%$ score. As expected, all the participants with more than 25 years of experience in the construction industry scored a full $100 \%$.

\section{Knowledge Scores for Site Supervisors in Construction Industry}

Results gathered from the site supervisors indicated that the correct answers were significantly related to age $(p<0.636)$ and total work experience in construction ( $p$ $<0.124$ ) (as shown in Table 2). Site supervisors who are younger than 25 years old and between 36 to 45 years old obtained an excellent score $100 \%$ compared to those who are more than 45 years old scoring only at $67 \%$. Meanwhile, site supervisors with less than five years of work experience gained $100 \%$ knowledge score while those with between 16 to 25 years of experience scored a surprising $67 \%$. This surprising result has definitely digressed from the initial expectation that knowledge would increase with more years of work experience.

\section{Knowledge Scores for Designers in Construction Industry}

The results obtained from the designers also indicated that characteristics such as gender, age and total of work experience had significant influences on the obtained scores $(p>0.05)$. All of the 33 male participants obtained an excellent score of $100 \%$ compared to only $89 \%$ score from female participants.

\section{Knowledge Scores for Contractors in Construction Industry}

Analysis of the knowledge scores of contractors was also associated with age $(p<0.269)$ and total work experience $(p<0.288)$. These results also revealed that participants who are younger than 25 years old and who are between 26 to 35 years old in total obtained an excellent $100 \%$ score. However, participants with more than 25 years of work experience in construction scored excellently at $100 \%$ compared to those with 16 to 25 years of work experience. 


\section{Identifying Knowledge Gaps}

Results obtained in identifying knowledge gaps among construction personnel have generally revealed that there is a significant difference in competency knowledge between site supervisors, designers and contractors based on the content of the safety training course syllabus (as shown in Table 3). The significant $p$-value is smaller than the alpha value 0.05 for Topics 7: Transportation and mobile plant, Topic 12: Installation of steel frame, Topic 13: Roof work, Topic 15: PPE, Topic 18: Working in water area, Topic 20: Welding and cutting, Topic 21: Manual work, Topic 23: Noise and vibration and Topic 25: Accident prevention. For Topic 1: Laws and regulations, Topic 2: Housekeeping and cleanliness, Topic 3: Fire prevention, Topic 4: Welfare facilities, Topic 5: Hazards from electric, Topic 6: Portable power tools, Topic 8: Crane, Topic 9: Hoist, Topic 10: Excavation, Topic 11: Demolition, Topic 14: Ladder usage, Topic 16: Scaffolding, Topic 17: Working on live roads, Topic 19: Confined space, Topic 22: Chemical dust and fumes and heat have significant $p$-values greater than alpha 0.05 values. The values demonstrated that there is no significant difference in competency knowledge among construction personnel.

Table 3. Frequencies of Correct Answers to Safety Training Knowledge Questions of All Construction Personnel in Construction

\begin{tabular}{|c|c|c|c|c|c|}
\hline \multirow[b]{2}{*}{ Question } & \multicolumn{4}{|c|}{ Correct Answer (\%) } & \multirow[b]{2}{*}{$p$-value } \\
\hline & $\begin{array}{l}\text { Overall } \\
(n=200)\end{array}$ & $\begin{array}{l}\text { Site } \\
\text { supervisor } \\
(n=23)\end{array}$ & $\begin{array}{l}\text { Designer } \\
(n=71)\end{array}$ & $\begin{array}{l}\text { Contractor } \\
(n=106)\end{array}$ & \\
\hline $\begin{array}{l}\text { Topic 7: Transportation and } \\
\text { mobile plant }\end{array}$ & & & & & 0.000 \\
\hline $\begin{array}{l}\text { Transportation for cylinder } \\
\text { gas }\end{array}$ & 78.0 & 91.3 & 57.7 & 88.7 & 0.000 \\
\hline $\begin{array}{l}\text { Proper way to keep } \\
\text { cylinder gas }\end{array}$ & 69.0 & 52.2 & 81.7 & 64.2 & 0.007 \\
\hline $\begin{array}{l}\text { Topic 12: Installation of steel } \\
\text { frame }\end{array}$ & & & & & 0.012 \\
\hline $\begin{array}{l}\text { Safety factor when lifting steel } \\
\text { frame }\end{array}$ & 86.5 & 100.0 & 84.5 & 84.9 & 0.131 \\
\hline $\begin{array}{l}\text { Safe installation of steel frame } \\
\text { components }\end{array}$ & 86.5 & 95.7 & 80.3 & 88.7 & 0.285 \\
\hline Topic 13: Roof work & & & & & 0.039 \\
\hline $\begin{array}{l}\text { The cause of the worker fall } \\
\text { from the roof }\end{array}$ & 62.0 & 60.9 & 66.2 & 59.4 & 0.732 \\
\hline Classification of fall from roof & 86.5 & 87.0 & 93.0 & 82.1 & 0.256 \\
\hline Topic 15: PPE & & & & & 0.000 \\
\hline The intended use of gloves & 56.5 & 78.3 & 40.8 & 62.3 & 0.002 \\
\hline $\begin{array}{l}\text { The intended use of safety } \\
\text { goggles }\end{array}$ & 84.0 & 87.0 & 83.1 & 84.0 & 0.045 \\
\hline
\end{tabular}


Table 3. (continued)

\begin{tabular}{|c|c|c|c|c|c|}
\hline \multirow[b]{2}{*}{ Question } & \multicolumn{4}{|c|}{ Correct Answer (\%) } & \multirow[b]{2}{*}{$p$-value } \\
\hline & $\begin{array}{l}\text { Overall } \\
(n=200)\end{array}$ & $\begin{array}{c}\text { Site } \\
\text { supervisor } \\
(n=23)\end{array}$ & $\begin{array}{l}\text { Designer } \\
(n=71)\end{array}$ & $\begin{array}{l}\text { Contractor } \\
(n=106)\end{array}$ & \\
\hline Topic 18: Working in water area & & & & & 0.030 \\
\hline $\begin{array}{l}\text { Safety measures when } \\
\text { working in water areas }\end{array}$ & 78.0 & 56.5 & 81.7 & 80.2 & 0.030 \\
\hline Topic 20: Welding and cutting & & & & & 0.043 \\
\hline Electric welding maintenance & 9.5 & 17.4 & 5.6 & 10.4 & 0.043 \\
\hline Topic 21: Manual work & & & & & 0.004 \\
\hline Formwork inspection & 21.5 & 8.7 & 28.2 & 19.8 & 0.034 \\
\hline Topic 23: Noise and vibration & & & & & 0.038 \\
\hline Exposure to noise & 42.5 & 43.5 & 52.1 & 35.8 & 0.000 \\
\hline Topic 25: Accident prevention & & & & & 0.011 \\
\hline $\begin{array}{l}\text { Factors contributing to the } \\
\text { accident }\end{array}$ & 77.0 & 78.3 & 87.3 & 69.8 & 0.032 \\
\hline $\begin{array}{l}\text { How to prevent accidents in } \\
\text { the use of elevators }\end{array}$ & 23.5 & 78.3 & 25.4 & 27.4 & 0.009 \\
\hline
\end{tabular}

\section{DISCUSSION}

This survey provides significantly important information regarding the level of competency knowledge among construction personnel in the construction industry holding different portfolios such as site supervisors, designers (which include architects, project manager, quantity surveyor and consulting engineers) and contractors based on safety training. It is generally assumed that by acquiring safety knowledge, construction personnel can enhance their skills and gain more positive attitude while increasing their competency level in performing their jobs. Construction personnel with high cognitive efficiency can support employees in yielding high quantity of work by appropriately addressing safety related issues. The inference statistics used in this study are aimed to analyse the differences in competency knowledge among construction personnel through Chi-square test. Therefore, only when the significant $p$-value is smaller than the alpha value 0.05 were taken into account in this study. This is because the value of 0.05 is set as a difference in competency knowledge among the construction personnel against the content in the safety syllabus. This is clearly presented in Topic 7: Transportation and mobile plant, Topic 12: Installation of steel frame, Topic 13: Roof work, Topic 15: PPE, Topic 18: Working in water area, Topic 20: Welding and cutting, Topic 21 : Manual work, Topic 23: Noise and vibration and Topic 25: Accident prevention.

This study has disclosed the results of competency knowledge among construction personnel by taking into account indicators such as gender, age and work experience in construction. Indicators of age and work experience in construction are seen to be more effective in determining the competency level 
of a person when working in a company. The selection of this indicator is in line with the study performed by Judge et al. (1995), Chileshe and Haupt (2010) and Reeve et al. (2012) which found that an individual's competency level and knowledge are closely related to age and experience which can be a determining factor for a successful career.

Gender also has some contributing factors in identifying certain characteristics among construction personnel. According to a study conducted by Lebar and Mansor (2007), Harding (1979) and Murphy (1982), male respondents were more likely to give correct answers in multiple-choice tests than female respondents. However, the present study has exhibited that even though most respondents who completed the questionnaire were male (66.0\%), results revealed that the difference is not significant in competency knowledge between male and female respondents.

Age is also a contributing factor when the construction personnel provide their responses in the questionnaire. The age classification is in line with age classification suggested by Kabacoff and Stoffey (2001), whereby between 25 to 35 years old is categorised as young while 45 to 55 years old is categorised as old. The current study found that there is a difference in competency knowledge among construction personnel mostly from those who are 45 years old and above because the age factor influences the level of their competence in responding to the questionnaire. This finding is consistent with the results reported in Gellis, Sherman and Lawrance (2003), Okoye (2004) and Cuddy, Norton and Fiske (2005) in which they proclaimed that age affects the way of thinking. It has also been suggested that older personnel are considered as individuals who are hard-pressed to receive training, are slower in adapting to a new technology and have lower stamina.

Results gathered from the respondents with less than five years work experience in construction revealed that this indicator also affects the level of knowledge among construction personnel. It was established in a study by Idrees, Hafeez and Kim (2017) that construction personnel would be more knowledgeable in dealing with construction related accidents when they have extensive experiences in their trade. The advantage of having years of experience with the job also allows construction personnel to estimate and avoid any possibilities of mishaps at work. Experiences in the trade would also furnish construction personnel with discipline in following protocols and arm them with the necessary skills in performing their tasks. It was also identified in the present study that knowledge increases in correspond with work experience among the respondents. With reports on the more frequent occurrences of construction accidents, it is indispensable for construction personnel of all levels to build awareness on construction hazards and safety.

Results gathered on the responses for Item 7 in the questionnaire showed that many of the construction personnel who participated in the study have inadequate knowledge of employees' safety especially when transporting gas cylinder at construction sites as more $85.0 \%$ of contractor and site supervisor gave correct answer compare with designer (57.7\%). This is lower compared to findings reported by Vermeulen (2014), who reported that $74 \%$ designer knew the safe practices when transporting gas cylinder on sites. On the other side, contractor and site supervisor were not aware of the basic requirement to keep cylinder gas. This statement is found to be true in a study by Sen et al. (2015) where construction employees did not exercise safe practices when loading and unloading gas cylinders on sites. It was also highlighted that imprudent method will not only cause physical site hazards but may also come at the cost of personal physiological well-being such 
as the development of "Musculoskeletal Disorders" (MSD) and back pain. Results from the present study also revealed that there is similarity to findings from Adnan and Ressang (2015) which demonstrated that ergonomic disorders in Malaysia are gradually in the increase annually due to employees' lack of awareness on safety at work and there is limited knowledge on the seriousness of ergonomic disease.

It is also interesting to describe findings collected for Item 12 which attempts to identify information on the occurrences of accidents caused by steel frame installations. The majority of construction personnel were aware of safety factor when lifting steel frame and installation of steel frame as more than $85 \%$ of all construction personnel gave correct answer. However, the data found in the analysis of this study have determined the existence of different competency levels in the installation of steel framework among construction personnel who participated in this study. It was identified that the occurrences of building collapsing is at $57 \%$ caused by failure of steel frame structures. In a study by Usmen and Vilniti (2015), it was found that $40 \%$ of the designers were responsible for the steel frame structure while the contractor's involvement was $60 \%$. Such difference may cause multifarious perspectives in construction management, inadequate planning and supervision, ineffective interpretation and assessment of safety rules. Other contributing factors which may lead to failure of steel frame structures include unclear workloads, poor communication between design groups, insufficient co-operation and training.

Looking at the results collected for Topic 13 involving roof work, it has been identified that occurrences of roof hazards is an unceasing concern. The difference in the age, experience and gender of construction personnel had influence on the knowledge score $(p<0.005)$. Findings in this study demonstrated corresponding results to that of a prior study from Mohammed and Ishak (2013) that falling from the roof is a major tragedy in the Malaysian construction industry. The reported accidents are usually caused by the lack of competency and knowledge in occupational safety and health at work especially when working on higher grounds or the roof. Additionally, roof top accidents include fatality among construction workers due to failure in identifying potential work hazards while working on the roof (Hamid, Majid and Singh, 2008). Therefore, the appropriate measures need to be thoroughly discussed and planned accordingly prior to roof top works.

The analysis looks on into Topic 15 which dwells into PPE. Results revealed that the competency level among construction personnel in this crucial area is still unsatisfactory. To top it all, they also have very low awareness on the importance of using the appropriate PPE while at work. An opposite to this study, Windapo (2011) reported that $87.1 \%$ contractors knew the importance of PPE while $87.8 \%$ of construction management knew that not wearing PPE can lead to major injuries (Tanko and Anigbogu, 2012). Also, much thought needs to be given especially when construction personnel not only are lacking in safety awareness but would have the inclination of ignoring using provided PPE while at work with such ignorance and imperturbable behaviour, it is not surprising that a lot of work hazards and accidents happen very frequently at the cost of not only work productivity but the lives of others.

It was also not surprising to find that poor competency knowledge among construction personnel also lead to many other unflustered attitude concerning the use of PPE at work even as simple as using protective gloves and protective glasses while on site. This has been proven by Tam and Fung (2008) who have identified that many employees are unaware of potential work hazards and the vulnerable 
situation that they put themselves into when not using provided PPE which comply with the health and safety regulations. Workers need to be given appropriate trainings and exposure on the advantages of using PPE in performing their specified jobs because not only the PPE serves as protection to them but also paves the way for more efficiency at work. Importantly, all protective equipment should be checked and assessed regularly to ensure they are in good working conditions.

The next topic which will be looked into is Topic 18 concerning working in water area. Working in aqueous area such as offshore requires a different level of safety measures and plans. The construction personnel who participated in this study have indicated that they have varying level of competency knowledge in this area. Nevertheless, contractor and designer seem to be more conscious of safety while working in water area compared to site supervisor (56.5\%). An opposite to this study, Hardison (2012) identified that supervisor need $100 \%$ competency knowledge in pre planning to control and prevention of hazards associated with high-risk area. It is significantly important for construction personnel to have sound competency knowledge when working in wet area and able to give appropriate responses when situation calls for quick decisions to be made. Working in water would call for adequate provisions of PPE, life-boat and other life-saving equipment suitable for works in the waters. However, Ajator, Ezezue and Agu (2017) identified that a handful evidence showed that many construction personnel have insufficient knowledge in health and safety for working in high-risk areas such as when working in deep waters.

Topic 20 looks into the practices when construction personnel perform welding and cutting activities at work. Considering construction personnels' knowledge on electrical welding maintenance, almost all of them (below 20\%) were not aware of the safety precaution while workers doing electrical welding maintenance. Similar findings was determined in the survey performed among site supervisor to have sound competency knowledge in welding activities was < 20\% (Hardison, 2012) while the findings reported by Vermeulen (2014) stated the designer has little effect $(35 \%)$ on the safety of construction employees for maintenance activities. Welding requires cautious steps and adequate equipment that comply with PPE safe specifications. When welding, insulating, curing and grounding wires, protective devices are necessary and should be given attention to. In a shocking finding by Z'gambo (2015), there are welders who do not adhere to precautionary measures that they deliberately did not use the safety equipment provided. Not only that, the management also failed to allocate appropriate area for storage leaving not only PPE but also welding equipment disorganised on site. Therefore, safety and health education and training is highly necessary but it will not be effective if the knowledge provided during training are not put into practice by all of the construction personnel.

Topic 21 seeks to identify the competency level among construction personnel concerning manual work. It is very alarming that construction personnel have low level of competency knowledge with regard to temporary works such as inspection of frameworks done by construction workers. Temporary works such as the erection of framework would have limited information when working around it due it its momentary structure. It was highlighted by Maloney (2011) that failures during temporary work is often due to its lack of detailed information such as when working with temporary moulding and demolishing of framework. Therefore, this calls for construction personnel diligence when doing site observations. 
Topic 23 discusses noise and vibration at work. Results revealed that competency level among the participating personnel varies in this matter. Construction personnel were not aware of the fact that noise and vibration can cause harm as $42.5 \%$ gave correct answer. It was put forth by Vitharana, De Silva and De Silva (2015) that construction personnel need not only trainings but also actions in ensuring workers to use PPE when working in sites with high noise and vibration exposure. Vibration and noise produced from various activities on site would also be hazardous when workers are exposed to the situation too much leading to various health hazards such as hearing impairment.

Topic 25 which involves accident prevention is an important area which needs significant attention when addressing the matter. Every project would require some interim plans which will look into major possibilities for accidents to occur. Making initial projections on the possibilities would provide insights for certain personnel to make their action plans should safety hazards emerge during work. It was highlighted by Chen, Lu and Huang (2011) that it is crucial for construction personnel to have sound knowledge in accident prevention to avoid the loss of lives and any hazards which may cause the health of workers and causing economical loss to the whole project. Therefore, a good action plan is crucial to prevent accidents at work and needs to be diligently dispersed to the whole team involved including to adhere to all health and safety regulations.

It is therefore necessary for all construction personnel including designers, engineers and those who work on sites to have sound knowledge in safety and health at the work place but importantly to practice every measure that they have knowledge to. This is supported by Ghule (2008) in which their findings suggested that the involvement and construction professional in the process of worker safety and address such failures accordingly, accidents at work could be avoided while still taking precautionary measures. Another worthy point that needs to be highlighted that all employees working on construction sites should not only have knowledge and training on safety and health at work but to enforce their knowledge in their daily activities on site. Every rules and regulations which could avoid work hazards should be diligently respected and adhere to.

\section{CONCLUSION}

The survey provides very important information on the level of competency knowledge in safety training among construction personnel. A questionnaire based on a multiple choice test were developed using induction training modules provided by CIDB. Based on the independent sample t-test and ANOVA with the Scheffe test, it was found that the knowledge score among construction personnel was significantly not associated with age and experience. From the Chi square test, it was found that there is a significant difference in competency knowledge among construction personnel on the content of the safety training course syllabus. The significant $p$-value is smaller than the alpha value 0.05 refers to the nine topics only which were Topics 7: Transportation and mobile plant, Topic 12: Installation of steel frame, Topic 13: Roof work, Topic 15: PPE, Topic 18: Working in water area, Topic 20: Welding and cutting, Topic 21: Manual work, Topic 23: Noise and vibration and Topic 25: Accident prevention. It was found that Topic 7: Transportation and mobile plant and Topic 15: PPE revealed the lowest competency knowledge among construction personnel. 
Results from this study might serve as a base for further improvement in the knowledge and training/educational materials and emphasise the necessity for continuous safety training among construction personnel. It is crucial for all construction personnel to receive adequate and more focused safety training that covers most important factors that contribute to construction accidents. It is often assumed that the safety training leads to knowledge based changes awareness in attitudes and practices on construction site. Individual cognition varies with age and experience might be the reason for the differences in the level of competency knowledge among construction personnel which also influence the success of the individual's career. Inadequate safety programs and current health and safety information for construction personnel had been identified as a barrier to implement safety knowledge and to curtail construction accidents. Therefore, to ensure adequate knowledge among construction personnel and to enhance the knowledge in health and safety, it is suggested that more specific training courses should be planned for construction personnel and regular evaluation should be carried out to ensure the effectiveness of the knowledge acquired in the safety training courses. Additionally, ongoing training should target every construction personnel on site, aim to provide health and safety education for everyone and to highlight the correct personal safety attitude, role and commitment.

\section{REFERENCES}

Adnan, N.H. and Ressang, A. (2016). Ergonomics awareness on construction site. Available at: http://civil.utm.my/wp-content/uploads/2016/12/ErgonomicsAwareness-on-Construction-Site.pdf [Accessed on June 2017].

Ajator, U.O., Ezezue, A.M. and Agu, N. (2017). Effective hazard control: An imperative for managing health, safety and environmental challenges of construction projects in Nigeria. Journal of Scientific and Engineering Research, 4(5): 31-43.

Alnunu, M.Z. and Maliha, M.R. (2015). Evaluation of factors affecting on safety performance at high workplace in Gaza Strip 2014. Journal of Civil and Environmental Engineering, 5(1): 1-5. http://doi.org/10.4172/2165$784 \mathrm{X} .1000167$.

Argote, L. (1999). Organizational Learning: Creating, Retaining and Transferring Knowledge. Boston: Kluwer Academic Publishers.

Ben-Simon, A., Budescu, D.V. and Nevo, B. (1997). A comparative study of measures of partial knowledge in multiple choice tests. Applied Psychological Measurement, 21: 65-88. https://doi.org/10.1177/0146621697211006.

Boyatzis, R. (1982). The Competent Manager. New York: Wiley.

Chen, W.T., LU, C.S. and Huang, Y.H. (2011). Investigating the safety cognition of Taiwan construction personnel. Journal of Marine Science and Technology, 19(4): 398-408.

Chen, W.T., Lu, C.S., Liu, S.-S. and Wang, M.-S. (2013). Measuring the perception of safety among Taiwan construction managers. Journal of Civil Engineering and Management, 19(1): 37-48. https://doi.org/10.3846/13923730.2012.7348 52.

Chileshe, N. and Haupt, T.C. (2010). The effect of age on the job satisfaction of construction workers. Journal of Engineering, Design and Technology, 8(1): 107-1 18. https://doi.org/10.1108/17260531011034682. 
Chiocha, C., Smallwood, J. and Emuze, F. (2011). Health and safety in the Malawian construction industry. Acta Structilia, 18(1): 68-80.

Cuddy, A.J.C., Norton, M.I. and Fiske, S.T. (2005). This old stereotype: The pervasiveness and persistence of the elderly stereotype. Journal of Social Issues, 61 (2): 267285. https://doi.org/10.1111/j.1540-4560.2005.00405.x.

Demirkesen, S. and Arditi, D. (2015). Construction safety personnel's perceptions of safety training practices. International Journal of Project Management, 33(5): 1160-1169. http://doi.org/10.1016/j.jproman.2015.01.007.

Department of Occupational Safety and Health (DOSH) (2012). Occupational accident 2012. Available at: http://www.dosh.gov.my/index. php? option=com_content \&view=article \&id=795:occupational-accidentsstatistics-2012\&catid=458\&ltemid=695\&lang=en [Accessed on March 2014].

Gellis, Z.D., Sherman, S. and Lawrance, F. (2003). First year graduate social work students' knowledge of and attitude toward older adults. Educational Gerontology, 29(1): 1-16. https://doi.org/10.1080/713844235.

Ghule, S.A. (2008). Suggested practices for preventing construction worker falls. MSc diss. University of Florida.

Goh, S.G. (2002). Managing effective knowledge transfer: An integrative framework and some practice implications. Journal of Knowledge Management, 6(1): 22-30. https://doi.org/10.1108/13673270210417664.

Gronlund, E. (1993). How to Make Achievement Tests and Assessments. 5th Ed. Boston, MA: Allyn and Bacon.

Gue, S.S. and Tan, Y.C. (2004). A proposed model for a sustainable engineering consulting firm. Paper presented at the World Engineers' Convention. Shanghai, China.

Hamid, A.R.A., Majid, M.Z.A. and Singh, B. (2008). Causes of accidents at construction sites. Malaysian Journal of Civil Engineering, 20(2): 242-259.

Harding, J. (1979). Sex differences in examination performance at 16+. Physics Education, 14: 280-288. https://doi.org/10.1088/0031-9120/14/5/305.

Hardison, D. (2012). Knowledge-based competencies necessary for the frontline construction supervisor: Improving safety through knowledge. MSc diss. East Carolina University.

Idrees, M.D., Hafeez, M. and Kim, J.Y. (2017). Workers' age and the impact of psychological factors on the perception of safety at construction sites. Sustainability, 5(9): 745. https://doi.org/10.3390/su9050745.

International Labour Organization (ILO) (2003). Safety in Numbers: Pointers for a Global Safety Culture at Work. Geneva: ILO.

Jones, M. and Saad, M. (2003). Managing Innovation in Construction. London: Thomas Telford Limited.

Judge, T.A., Cable, D.M., Boudreau, J.W. and Bretz, R.D. (1995). An empirical investigation of the predictors of executive career success. Personnel Psychology, 48: 485-519. https://doi.org/10.1111/j.1744-6570.1995.tb01767.x.

Kabacoff, R.I. and Stoffey, R.W. (2001). Age differences in organisational leadership. Paper presented at the 16th Annual Conference of the Society for Industrial and Organisational Psychology. San Diego, California, April.

Langford, D., Rowlinson, S. and Sawacha, E. (2000). Safety behavior and safety management: Its influence on the attitudes of workers in the UK construction industry. Engineering, Construction and Architectural Management, 7(2): 133-140. https://doi.org/10.1046/j.1365-232X.2000.00137.x. 
Lebar, O. dan Mansor, N. (2007). Pencapaian pelajar mengikut gaya belajar dan bentuk pentaksiran. Available at: http://jpnperak.edua.my/portal/modules. php? name=News\&file=article\&sid=34 [Accessed on 3 June 2006].

Lubega, H. Kiggundu, B.M. and Tindiwensi, D. (2000). An investigation into the causes of accidents in the construction industry in Uganda. Available at: www.irbnet. de/daten/iconda/CIB8913.pdf [Accessed on March 2017].

Maloney, F.W. (2011). Conceptual model of safety culture for construction. Paper presented at the CIB W099 Conference on Safety and Health in Construction. Washington DC, 24-26 August.

Merwe, H.V.D. (2015). Quality assuring multiple-choice question assessment in higher education. South African Journal of Higher Education, 29(2): 279-297. https:// doi.org/10.20853/29-2-473.

Ministry of Education Malaysia (2016). Integrated evaluation of components success of educational services (PBPPP). The Development and Evaluation of Competence. Putrajaya: Ministry of Education Malaysia.

Mohamed, O., Abdul-Rahman, H., Othman, M., Yahya, I.A. and Zakaria, N. (2007). Are knowledge management levels and efforts in construction sufficient?: The case of a developing economy. Malaysian Construction Research Journal, $1(1): 40-56$.

Mohammed, Y.D. and Ishak, M.B. (2013). A study of fatal and non-fatal accidents in construction sector. Malaysian Journal of Civil Engineering, 25(1): 106-1 18.

Murphy, R.J.L. (1982). Sex differences in objective test performance. British Journal of Education Psychology, 52(2): 213-219. https://doi. org/10.1111/j.2044-8279.1982.tb00828.x.

Okoye, U.O. (2004). Knowledge of aging among secondary school students in south-eastern Nigeria. Educational Gerontology, 30(6): 481-489. https://doi. org/10.1080/03601270490445096.

Reeve, R., Reynolds, F., Humberstone, J. and Butterworth, B. (2012). Stability and change in markers of core numerical competencies. Journal of Experiential Psychology, 141 (4): 649-666. https://doi.org/10.1037/a0027520.

Salleh, Z., Mazlan, E.M., Mazlan, S.A., Hassan, N.A. and Patakor, F.A. (2011). A case study on the efficacy of technical laboratory safety in polytechnic. International Journal of Social, Behavioral, Educational, Economic, Business and Industrial Engineering, 5(5): 632-636.

Schindler, M. and Eppler, M.J. (2003). Harvesting project knowledge: A review of project learning methods and success factors. International Journal of Project Management, 21 (3): 219-228. https://doi.org/10.1016/S0263-7863(02)00096-0.

Sen, K.N., Elangovan, R.K., Shrihari and Siddiqui, N.A. (2015). Safe handling of gas cylinder at construction site. International Journal of Advanced Engineering Technology, 6(1): 18-22.

Tam, C.M., Fung, W.H., Yeung, C.L. and Tong, C.F. (2003). Relationship between construction safety signs and symbols recognition and characteristics of construction personal. Construction Management and Economics, $21(7)$ : 745-753. https://doi.org/10.1080/0144619032000056171.

Tam, C.M., Zeng, S.X. and Deng, Z.M. (2004). Identifying elements of poor construction safety management in China. Safety Science, 42: 569-586. https://doi. org/10.1016/j.ssci.2003.09.001. 
Tam, V.W.Y. and Fung, I.W.H. (2008). A study of knowledge, awareness, practice and recommendations among Hong Kong construction workers on using personal respiratory protective equipment at risk. The Open Construction and Building Technology Journal, 2: 69-81. https://doi.org/10.2174/1874836800802010069.

Tanko, B.L. and Anigbogu, N. (2012). The use of personal protective equipment (PPE) on construction sites in Nigeria. Paper presented at the West Africa Built Environment Research (WABER) Conference. 24-26 July, Abuja, Nigeria.

Teck, A.G.P., Asmoni, M.N.A., Misnan, M.S., Jaafar, M.N. and Mei, J.L.Y. (2015). A review on the effectiveness of safety training methods for Malaysia construction industry. Jurnal Teknologi, 74(2): 9-13. https://doi.org/10.11113/ j†.v74.4518.

Usmen, M.A. and Vilniti, M. (2015). Evaluation of safety, quality and productivity in construction. IOP Conference Series: Materials Science and Engineering, 96: 012061. https://doi.org/10.1088/1757-899X/96/1/012061.

Vermeulen, B. (2014). The role of a design engineer in safety of building projects. MEng diss. Stellenbosch University.

Vitharana, V.H.P., De Silva, G.H.M.J.S. and De Silva, S. (2015). Health hazards, risk and safety practices in construction sites: A review study. Engineer: Journal of the Institution of Engineers, Sri Lanka, 48(3): 35-44. https://doi.org/10.4038/ engineer.v48i3.6840.

Windapo, A.O. (2011). Investigation into the level of compliance to construction health and safety requirements within the South African construction industry. Paper presented at the CIB W099 Conference on Safety and Health in Construction. Washington DC, 24-26 August.

Z'gambo, J. (2015). Occupational hazards and use of personal protective equipment among small scale welders in Lusaka, Zambia. MPhil diss. University of Bergen. 